\title{
A Comparative Study of Serum Uric Acid Level in First Degree Relatives of Patients of Acute Coronary Syndrome and In Normal Subjects
}

\author{
Authors \\ Dr Subha Bhakta ${ }^{1}$, Dr Geeta Baruah ${ }^{2}$, Dr D.J. Dutta ${ }^{3}$ \\ ${ }^{1}$ Demonstrator, Department of Physiology, Assam Medical College, Dibrugarh-786002, Assam, India \\ ${ }^{2}$ Professor, Dept of Physiology, Fakhruddin Ali Ahmed Medical College, Barpeta-781301, Assam, India \\ ${ }^{3}$ Professor, Department of Cardiology, Assam Medical College, Dibrugarh-786002, Assam, India \\ Corresponding Author

\section{Dr Subha Bhakta}

Department of Physiology, Assam Medical College, Dibrugarh, Assam-786002

Email:subha84b@gmail.com, Mobile no: 9435678993

\begin{abstract}
Background: Ischaemic heart disease (IHD) is a leading cause of worldwide morbidity and mortality. A number of risk factors have been described in the etiology of IHD. Uric acid is one of the modifiable risk factor plays a role in the development of cardiovascular morbidity in the general population. We can delay the development of IHD by better control of uric acid levels in first degree relatives (FDRs) of IHD patients. We conducted a study in which we were assess serum uric acid levels independent of other established risk factors in FDRs of IHD patients and in normal subjects.

Method: Sixty first degree relatives of IHD patients were selected, who were the attendants of the patients coming to the cardiology OPD and patients admitted to Intensive Care Unit (ICU), Assam Medical College Dibrugarh. An equal number of subjects were selected as a control group who had no family history of IHD. After a detailed clinical history and physical examination, fasting blood samples were collected. Blood glucose, lipid profile and serum uric acid levels were estimated.

Results: The serum uric acid levels were found to be significantly high in first degree relatives of acute coronary syndrome in comparison to healthy individuals.

Conclusion: . We therefore conclude that high uric acid has a definite role in Cardiovascular disease in first degree relatives.

Key Words: Ischaemic heart disease (IHD), Coronary artery disease (CAD), First Degree Relatives (FDRs), Intensive Care Unit (ICU), serum uric acid (SUA).

\section{Introduction}

Coronary artery disease (CAD) is a life threatening disease and leading cause of death all over the world. Acute coronary syndrome which is a clinical manifestation of Ischemic Heart Disease, comprising unstable angina, acute myocardial infarction and sudden death ${ }^{(1),(2)}$ All

forms of ACS are characterized by an imbalance between myocardial oxygen supply and demand, and many other factors also contribute to this imbalance. The common pathophysiological mechanism of ACS is atherosclerotic plaque rupture or erosion, with differing degrees of superimposed thrombosis and distal embolisation.
\end{abstract}


Atherosclerosis is the hallmark of CAD, occurring by deposition of yellow fibro fatty plaques known as atheroma which contains cholesterol, lipid and lipophages along with uric acid crystals.

The association between serum uric acid (SUA) levels and the risk for vascular disease is controversial. Several studies in the general population suggested that elevated SUA levels are independently related to increased vascular morbidity and mortality. However, in other studies this relationship was not significant.

Elevated uric acid levels have been found to be associated with increased platelet aggregability and its activation thereby increasing the risk of coronary thrombosis. Uric acid has also been found to promote LDL oxidation in vitro, which is a key step in progression of atherosclerosis

Uric acid, a product of purine metabolism, is degraded in most mammals by hepatic enzyme, Uri-case to allantoin. Serum uric acid in the early stages of atherosclerotic process is known to act as an anti-oxidant. It may be one of the strongest determinants of plasma antioxidant capacity. ${ }^{(3),(4)}$ Thus; it may become prooxidant in atherosclerotic vessels due to certain conditions (timing; acidity and surrounding oxidant milieu) which are different from the normal vessels. Therefore, it is proposed that there is an existence of antioxidantpro-oxidant redox shuttle in the atherosclerotic micro vascular intima. ${ }^{(5)}$ Many recent studies has proved higher serum level of uric acid associated with ischemic heart disease. Serum uric acid is a graded marker of risk for the development of cardiovascular disease compared to patients with normal serum uric acid levels. It is specially observed in those with serum uric acid in the upper half of its normal physiological range. ${ }^{6}$ Hence, elevation of serum uric acid to more than $4 \mathrm{mg} / \mathrm{dl}$ should be considered as - red flag in those patients at risk of developing IHD. This increase in serum uric acid should alert the clinicians to strive to utilize the global risk reduction programme to reduce the morbidity and mortality associated with $\operatorname{IHD}^{(7),(8) .}$
Hence, the present study was planned to explore the role of uric acid in causation of CAD and whether it act as an independent risk factor or in combination with other parameters.

\section{Material and Methods}

After obtaining ethical clearance from the institutional ethical committee,. The study was conducted in the Department of Physiology, Assam Medical College \& Hospital, Dibrugarh for a period of one year. The study group consisted of apparently healthy subjects, who are first degree relatives (FDRs) of patients of acute coronary syndrome admitted to the ICU or coming to the Cardiology OPD , $\mathrm{AMCH}$, Dibrugarh. A total of 60 cases were taken for the study after considering the exclusion criteria. Sixty healthy people with no history of ischaemic heart disease in family, matching age and gender as in first degree relatives were also studied as a control group. Criterion for inclu-sion of subjects was that they had one or more first degree relatives who were known cases of IHD. Exclusion criteria were the same for both first degree relatives and controls i.e. who were known diabetics, known hypertensive, smokers, obese, Renal disease, Gout ,Heart disease and had abnormal lipid profiles.

Under all aseptic and antiseptic conditions $5 \mathrm{ml}$ of fasting blood sample was collected from each subject from a suitable peripheral vein by venepuncture using a sterile disposable syringe into a sterile empty vial. The same sample was then allowed to clot for 20-30 minutes and then centrifuged at 3000 RPM for separation of serum . This serum was then used for estimation for serum uric acid, lipid profile and blood glucose. The serum sample was processed as early as possible, i.e. the same day that it was collected. The data analysis was carried out by using SPSS (Ver.20). Results were expressed as Mean \pm Standard Deviation. The statistical significance of difference between the various groups was determined by using the ANOVA and Odds ratio (OR) was used to determine the strength of 
association and the approximation of relative risk. $P$ value was considered to be not significant when $\mathrm{p}>0.05$, moderately significant when between 0.05 to 0.001 and highly significant when $p<0.0$

\section{Results}

Out of 60 cases of first degree relatives of acute coronary syndrome $39(60 \%)$ were male and 24 $(40 \%)$ cases were females giving overall ratio of 3:2.

The mean Serum Uric Acid level in 60 cases of First degree relatives (FDRs ) of Acute coronary syndrome (ACS) was $5.07 \pm 1.53$ which was significantly ( $\mathrm{p}<0.05)$ high compared to Control $(4.05 \pm 1.06 \mathrm{mg} / \mathrm{dl})$.

In FDRs of ACS the mean value of SUA was high in both age group as compared to Control group but which was not statistically significant (p>0.05) .

SUA in both sexes of FDRs of ACS was increased $($ Male $=5.57 \pm 1.54 \&$ Female $=4.33 \pm 1.23)$ as compared to control group (Male $=4.14 \pm 1.03 \&$ Female $=3.92 \pm 1.11$ ) , but significant difference $(p<0.05)$ was only observed in case of male FDRs of ACS .

There were $34(56.67 \%)$ first degree relatives of ACS with the SUA levels less than $5 \mathrm{mg} / \mathrm{dl}$ whereas 26(43.33\%) in FDRs of ACS. There were $49(81.67 \&)$ cases in control group with values less than $5 \mathrm{mg} / \mathrm{dl}$ while $11(18.33 \%$ ) cases had more than $5 \mathrm{mg} / \mathrm{dl}$.

Odds ratio(OR $)=3.571,95 \%$ Confidence Interval :1.525-8.365, $\mathrm{P}<0.05$ and Pearson's coefficient (R)-0.275, P $<0.05$ were calculated by taking $\leq 5$ as reference group. And it showed that first degree relatives of acute coronary syndrome with high uric acid levels i.e. $>5 \mathrm{mg} / \mathrm{dl}$ were at 3.6 times at risk of developing acute coronary syndrome than one with low uric acid levels.
Table 1: Age and Sex wise distribution of Cases and Control

\begin{tabular}{|l|l|l|l|l|l|l|l|l|}
\hline \multicolumn{4}{|l|}{ Cases } & \multicolumn{3}{l|}{ Control } \\
\hline $\begin{array}{l}\text { Age } \\
\text { gr } \\
\text { (years) }\end{array}$ & $\begin{array}{l}\text { No } \\
\text { of } \\
\text { Ma } \\
\text { le }\end{array}$ & $\begin{array}{l}\text { Pe } \\
\text { rce } \\
\text { nta } \\
\text { ge }\end{array}$ & $\begin{array}{l}\text { No. } \\
\text { of } \\
\text { Fem } \\
\text { ale }\end{array}$ & $\begin{array}{l}\text { Percen } \\
\text { tage }\end{array}$ & $\begin{array}{l}\text { No } \\
\text { of } \\
\text { Ma } \\
\text { le }\end{array}$ & $\begin{array}{l}\text { Per } \\
\text { cen } \\
\text { tag } \\
\text { e }\end{array}$ & $\begin{array}{l}\text { No. } \\
\text { of } \\
\text { Fem } \\
\text { ale }\end{array}$ & $\begin{array}{l}\text { Perce } \\
\text { ntage }\end{array}$ \\
\hline $20-30$ & 18 & 30 & 10 & 16.67 & 18 & 30 & 10 & 16.67 \\
\hline $31-40$ & 18 & 30 & 14 & 23.33 & 18 & 30 & 14 & 23.33 \\
\hline Total & 39 & 60 & 24 & 40 & 36 & 60 & 24 & 40 \\
\hline
\end{tabular}

Table-2 Mean \pm SD of Serum uric acid levels in Cases and Control

\begin{tabular}{|l|l|l|l|l|}
\hline \multicolumn{2}{|c|}{} & \multicolumn{3}{|l|}{ Serum Uric Acid level (mg/dl) } \\
\cline { 3 - 4 } \multicolumn{2}{|l|}{ Groups } & $\begin{array}{l}\text { Mean } \pm \\
\text { SD }\end{array}$ & Range & P value \\
\hline \multirow{2}{*}{ Cases } & $\begin{array}{l}\text { FDRs of } \\
\text { ACS } \\
(\mathrm{n}=60)\end{array}$ & $\begin{array}{r}5.07 \\
\pm 1.53\end{array}$ & $3.00-8.10$ & \multirow{2}{*}{$<0.05^{*}$} \\
\hline \multirow{2}{*}{ Control $(\mathrm{n}=60)$} & $\begin{array}{l}4.05 \pm \\
1.06\end{array}$ & $2.00-6.10$ & \\
\hline
\end{tabular}

Table 3: Sex wise distribution of serum uric acid level in Cases and Controls

\begin{tabular}{|c|c|c|c|c|c|}
\hline \multirow{3}{*}{$\begin{array}{l}\text { Study } \\
\text { groups }\end{array}$} & \multicolumn{5}{|c|}{ Serum uric acid $(\mathrm{mg} / \mathrm{dl})$} \\
\hline & \multicolumn{2}{|l|}{ Male } & \multicolumn{3}{|l|}{ Female } \\
\hline & $\begin{array}{l}\text { Mea } \\
\mathrm{n} \quad \pm \\
\mathrm{SD}\end{array}$ & $\begin{array}{l}\text { Rang } \\
\text { e }\end{array}$ & $\begin{array}{l}\text { Mean } \pm \\
\mathrm{SD}\end{array}$ & Range & \\
\hline Cases & $\begin{array}{l}5.57 \\
\pm 1.5 \\
4 \\
\end{array}$ & $\begin{array}{l}3.00- \\
8.10\end{array}$ & $\begin{array}{l}4.33 \\
\pm 1.23\end{array}$ & $\begin{array}{l}3.42 \\
7.20\end{array}$ & \\
\hline Control & $\begin{array}{l}4.14 \\
\pm \\
1.03\end{array}$ & $\begin{array}{l}2.20- \\
6.10\end{array}$ & $\begin{array}{l}3.92 \\
\pm 1.1\end{array}$ & $\begin{array}{l}2.00 \\
6.10\end{array}$ & \\
\hline $\mathrm{P}$ value & \multicolumn{2}{|c|}{$<0.05^{*}$} & \multicolumn{3}{|l|}{$>0.05$} \\
\hline
\end{tabular}

Table 4: Age wise distribution of serum uric acid level in Cases and Controls

\begin{tabular}{|c|c|c|c|c|c|}
\hline \multirow{3}{*}{$\begin{array}{l}\text { Age } \\
\text { ( Years) }\end{array}$} & \multicolumn{5}{|c|}{ SERUM URIC ACID(mg/dl) } \\
\hline & \multicolumn{2}{|l|}{ Control } & \multicolumn{2}{|l|}{ Cases } & $P$ value \\
\hline & $\begin{array}{l}\text { Mean } \\
\pm \text { SD }\end{array}$ & $\begin{array}{l}\text { Ran } \\
\text { ge }\end{array}$ & $\begin{array}{l}\text { Mean } \\
\pm \text { SD }\end{array}$ & $\begin{array}{l}\text { Rang } \\
\mathrm{e}\end{array}$ & $P$ value \\
\hline $20-30$ & $\begin{array}{l}3.89 \pm \\
1.04\end{array}$ & $\begin{array}{l}2.00 \\
- \\
5.80\end{array}$ & $\begin{array}{l}5.04 \\
\pm \\
1.49\end{array}$ & $\begin{array}{l}3.00- \\
7.20\end{array}$ & $<0.05 *$ \\
\hline $31-40$ & $\begin{array}{l}4.19 \\
\pm 1.07\end{array}$ & $\begin{array}{l}2.00 \\
- \\
6.10\end{array}$ & $\begin{array}{l}5.101 \\
\pm 1.62\end{array}$ & $\begin{array}{l}3.42- \\
8.10\end{array}$ & $>0.05 * *$ \\
\hline
\end{tabular}


Table 5: Serum uric acid levels in Cases and Control

\begin{tabular}{|c|c|c|c|c|}
\hline \multirow{2}{*}{$\begin{array}{l}\text { Serum } \\
\text { uric acid } \\
\text { level } \\
(\mathrm{mg} / \mathrm{dl})\end{array}$} & \multicolumn{2}{|l|}{ Cases } & \multicolumn{2}{|l|}{ Control } \\
\hline & $\begin{array}{l}\text { No. of } \\
\text { cases }\end{array}$ & $\begin{array}{l}\text { Percentag } \\
\mathrm{e}\end{array}$ & $\begin{array}{l}\text { No. of } \\
\text { control }\end{array}$ & Percentage \\
\hline$\leq 5$ & 34 & 56.67 & 49 & 81.67 \\
\hline$>5$ & 26 & 43.33 & 11 & 18.33 \\
\hline Total & 60 & 100 & 60 & 100 \\
\hline
\end{tabular}

\section{Discussion}

Acute coronary syndrome (ACS) is the commonest disease of the heart not only in India but also elsewhere in the world. The risk is uniformly increasing in young and females.(9)

Conventional risk factors do not account for all cases of Ischemic heart disease but still occurs in people with known risk factors. Among the growing list of risk factors for ischemic heart disease, serum uric acid is a potentially modifiable risk factor.

This study was specifically designed to determine the serum uric acid in the high risk group in order to evaluate their future risk of developing ischemic heart disease. The aim of the present study was to determine the levels of serum uric acid in first degree relatives of acute coronary syndrome patients, as independent predictors to develop acute coronary syndrome, irrespective of known conventional risk factors i.e. (diabetes mellitus, hypertension, hyperlipidaemia and smoking). ${ }^{(10),(11-14)}$

Independent association of high serum Uric Acid with cardiovascular disease have explored by numerous clinical and epidemiological studies . Such studies confirmed that elevated uric acid was a predictor of cardiovascular disease. Similar association was also found in the present study . Another study by Jiunn-Horng Chen et al (15), 2009 reported Hyperuricemia as an independent risk factor of mortality from all causes. Rotterdam Study (16), Hamidreza Goodarzynejad et al (17) (2009), Milionis HJ et al (2005) ${ }^{(18),}$ Bos MJ et al $(2006)^{(16)}$,Tushar B et al $(2011)^{(19)}$ reported serum uric acid as a risk factor for ischemic heart disease.

In the present study serum uric acid was found to be higher in FDR's of ACS patients as compared to normal subjects. This association of uric acid with ACS has been observed in a number of studies. ${ }^{(19),(20)}$ A study done on uric acid in first degree relatives of ischemic heart disease by $\mathrm{N}$. Mahmood et al ${ }^{(21)}$ ( 2008 to 2009 ) and found that uric acid levels were higher in FDRs as compared to normal subjects..

Another objective of this study was to determine relation between family history of Acute coronary syndrome and serum uric acid level. Serum uric acid increased significantly with an increase in incidence of ischemic heart disease in the family.

The Pearson's correlation formula was used and showed a significant positive correlation( $\mathrm{r}=$ $0.275, \mathrm{P}<0.05$ )of serum uric acid with family history. Similarly, N. Mahmood et al study also showed a significant positive correlation $(r=0.289$, $\mathrm{P}<0.05)$ between serum uric acid and family history. Torbus-Lisiecka et al ${ }^{(22)}$ also showed a positive correlations between the parents and children $(\mathrm{r}=0.71 \mathrm{p}<0.001)$. Pai-Feng Hsu et al (23), 2013 reported an association between family history and high uric acid with cardiovascular disease.

The main limitation of this study is that these FDR's should have been followed up as it has been observed that if these people are followed up regularly they are likely to develop ischemic heart disease earlier than those with normal levels.

\section{Conclusion}

From the present study the serum uric acid levels were found to be significantly high in first degree relatives of acute coronary syndrome in comparison to healthy individuals. On the other hand, family history acts as a major risk factor in the occurrence of CVD, and uric acid levels were found to be high in this group of population. Therefore, we came to the conclusion that high uric acid has a definite role in CVD and thus by estimating the uric acid level in first degree 
relatives; we can screen out the individuals that may have the chance of developing CVD in future. These findings are consistent with the earlier studies which have showed a positive correlation between serum uric acid and family history and established uric acid as an independent risk factor for first degree relatives of ischemic heart disease.

But regarding the usefulness of uric acid as marker of cardiovascular risk factor as well as to know the mechanism by which uric acid play role in the pathophysiology of ischemic heart disease , futher follow up studies and studies comprising of large number of cases and longer duration of study are required.

\section{References}

1. Yusuf S, Dunpuu S, Anand S. Global burden of cardiovascular disease. Circulation 2001; 104: 2855-2864.

2. Anthony S. Fauci, Eugene Braunwald, Dennis L. Kasper, Stephen L. Hauser, Dan L. Longo, J. Larry Jameson, Joseph Loscalzo. Disorders of the cardiovascular system: In: Harrrison's Textbook of Internal Medicine, Vol-II, $17^{\text {th }}$ Edition, 2008: p: 1365-1576.

3. Nyyssonen K, Porkkala SE, Salonen JT et al. Ascorbate and urate are the strongest determinants of plasma anti-oxidative capacity and serum lipid resistance to oxidation in Finish men. Atherosclerosis 1997; 130: 223-233.

4. Ishizaka N, Ishizaka Y, EiIchi T, Nagai R, Yamakado M. Association between serum uric acid, metabolic syndrome, and carotid atherosclerosis in Japanese individuals. Arterioscler Thromb Vasc Biol. 2005; 25: 1038-1044.

5. Nieto FJ, Iribarren C, Gross MD, Cosmotock GW, Cutler RG. Uric acid and serum antioxidant capacity: a reaction to atherosclerosis? Atherosclerosis. 2000; 148: 131-139.
6. Niskanen LK, Laaksonen DE, Salonen JT et al. Uric acid level as a risk factor for cardiovascular and all cause mortality in middle aged men: a prospective cohort study. Arch Intern Med 2004; 164: 154651.

7. Tyagi SC. Intimal redox stress: accelerated atherosclerosis in metabolic syndrome and type 2 diabetes mellitus. Atheroscleropathy Cardiovas Diabetol 2002; 1: 3. Doi: 10.1186/1475/-2840-1-3.

8. Hayden MR, Tyagi SC. Uric acid: A new look at an old risk marker for cardiovascular disease, metabolic syndrome and type 2 diabetes mellitus. The urate redox shuttle. Nutrition and Metabolism 2004; 1: 10.

9. Jaffar T, Jafary F, Jessani S. Heart disease epidemic in Pakistan: Females and males are at an equal risk. Am Heart J 2005; 150: 221-226.

10. Christopher J. Weir, PhD; Scott W. Muir, MBChB, MRCP; Matthew R. Walters, MD, MRCP; Kennedy R. Lees, MD, FRCP. Serum Urate as an Independent Predictor of Poor Outcome and Future Vascular Events After Acute Stroke .Stroke. 2003; 34: 1951-1956.

11. Wheeler JG, Juzwishin KD, Eiriksdottir G, Gudnason V, Danesh J. Serum uric acid and coronary heart disease in 9,458 incident cases and 155,084 controls : prospective study and meta - analysis. PLOS Med. 2005; 2 (3): e76.

12. W.S. Waring, D.J. Webb and S.R.J. Maxwell. Uric acid as a risk factor for cardiovascular disease. Q J Med 2000; 93: 707-713. 20.

13. Liese AD, Hense HW, Lowel H, Doring A, Tietze M. Association of SUA with all - cause and CVD mor-tality and incident MI in the MONICA Augsburg cohort. WHO Monitoring Trends and Determinants in CVD's. Epidemiology 1999; 10: 391-397. 
14. Bengtsson C, Lapidus L, Stendahl C, Waldenstrom J. Hyperuricaemia and risk of cardiovascular disease and overall death. A 12 - year follow-up of participants in the population study of women in Gothen-burg, Sweden. Acta Med Scand 1988; 224: 549-555.

15. Jiunn-Horng Chen, Shao-Yuan Chuang, Hsin-Jen Chen, Wen-Ting Yeh, and WenHarn Pan, Serum Uric Acid Level as an Independent Risk Factor for All-Cause, Cardiovascular, and Ischemic Stroke Mortality: A Chinese Cohort Study . Arthritis \& Rheumatism (Arthritis Care \& Research); 2009, pp 225-232

16. Bos MJ, Koudstaal PJ, Hofman A, Witteman JC, BretelerMM. Uric acid is a risk factor for myocardial infarction and stroke: the Rotterdam study. Stroke.2006;37(6):1503-1507

17. Hamidreza Goodarzynejad, MD, Maryam Sotoudeh Anvari, MD, Mohammad Ali Boroumand, MD, Abbasali Karimi, MD, Seyed Hesameddin Abbasi, MD, Gholamreza Davoodi, MD. Hyperuricemia and the Presence and Severity of Coronary Artery Disease. January 2010; DOI: 10.1309/LMKDB9PBKZGUS20T, Vol 41 Number 1 , LABMEDICINE 40-44

18. Milionis HJ, Kalantzi KJ, Goudevenos JA, Seferiadis K,Mikhailidis DP, Elisaf MS. Serum uric acid levels and risk for acute ischaemic non-embolic stroke in elderly subjects. J Intern Med05; 258 (5):435-441.

19. Tushar B. Patila, c, Amit S. Pasaria, Kiran M. Sargarb, Vinayak E. Shegokara, Yogendra V. Bansoda, Mangesh B. Patila2011 J Neurol Res. Serum Uric Acid Levels in Acute Ischemic Stroke: A Study of 100 Patients - 2011;1(5):193-200.

20. Bonora E, Targher G,Zeneree MB, Saggiani F, Cacciatori V, Tosi F, Travia D, Zenti MG, Branzi P, Santi L, Muggeo M. Relationship of uric acid concentration to cardiovascular risk factors in young men. Role of obesity and central fat distribution. The Verona Young men Atherosclerosis Risk Factors Study. Int J Obes Relat Metab Disord 1996; 20:97580.

21. Nadia Mahmood, Iram Fayyaz and Robina Basshir) . Comparision of uric acid levels in first degree relatives of ischemic heart disease and normal population. D:/Biomedica Vol.26, Jul. - Dec. 2010/Bio-2.Doc P. $101-104$

22. $\operatorname{Lp}(\mathrm{a})$, homocysteine and a family history of early ischemic cerebral stroke. TorbusLisiecka B, Bukowska H, Jastrzebska M, Chelstowski K, Honczarenko K, Naruszewicz M. Nutr.Metab Cardiovasc dis. 2001 Oct;11 Suppl 5:52-9 .

23. Pai-Feng Hsu, Shao-Yuan Chuang, WenChung $\mathrm{Yu}$, Hsin-bang Leu, Wan-Leong Chan and Chen-Huan Chen. The Impacts of Serum Uric Acid on arterial hemodynamics and Cardiovascular Risks2013. Acta Cardiol Sin 2013;29:142150 